\title{
TWO NEW SPECIES OF OPPOSITE-LEAVED ILEX FROM BORNEO
}

\author{
E. D. Merrill
}

In STUdying some of the celastraceous material of the large Clemens collection from Mount Kinabalu, Borneo, my attention was called to the two species considered below, partly because in the distribution of the duplicate sets some of the material had been placed under Microtropis, and some merely indicated as possibly representing the Celastraceae. When I went over the material to make further possible sight identifications, preliminary to its distribution into the herbarium, I had added Ilex to several of the sheets. Of one species fairly complete material is available, with immature buds, mature and expanded $\hat{o}$ flowers, immature and mature fruits, and morphologically all characters of the flowers and fruits are those of Ilex; yet both species have strictly opposite leaves, a character hitherto unrecorded for the Aquifoliaceae. In this family, and in all the numerous species of Ilex that hitherto have been proposed and described, the leaves are strictly alternate, although in a few cases they may be pseudo-verticillate by great shortening of the internodes and the resultant crowding of the upper leaves. Yet in these Bornean species all internodes are greatly elongated, and on all the specimens examined there is not a trace of alternate leaves.

The wood structure of Ilex oppositifolia Merr. has been examined by Miss F. L. Freeman, under the supervision of Prof. I. W. Bailey, her report being that the wood structure conforms to Ilex in all respects. This is confirmed by a report rendered by Prof. S. J. Record of the Yale Forestry School.

Personally I do not believe that a species or a small group of species, conforming to its congeners in all respects as to floral and fruit morphology and in its wood structure, but differing from the described species within the category in having strictly opposite rather than alternate leaves, is worthy of segregation as a genus or as a section or subgenus, and accordingly the two species involved are here placed in Ilex. The standard descriptions of the Aquifoliaceae and of the genus Ilex are to be modified by indicating that rarely opposite leaves are found instead of strictly alternate ones.

If any other confirmation of the correctness of my contention that Ilex is represented by the two opposite-leaved species described below, I would call attention to an unquestionable species of Ilex represented by 
Clemens 27877, from Mount Kinabalu, Jan. 7, 1932. This remarkably resembles and strongly suggests the two species here considered, even to the cymose-umbellate few-flowered inflorescences and the shape and texture of its leaves. Here, however, the lower leaves are strictly alternate with internodes up to $2.5 \mathrm{~cm}$. long, while the uppermost ones are subopposite and subverticillate, the uppermost leaves being spaced on the nodes from less than 1 to $3 \mathrm{~mm}$. Both species may belong in Subgenus Byronia, Series Eubryonia, although Subgenus Euilex, Series Lioprinus, Section Excelsae is not excluded by Loesener's not very definite characterizations.

This study has been based on the several numbers of the Clemens collection preserved in the herbaria of the Arnold Arboretum, the New York Botanical Garden, the Rijks Herbarium, Leiden, the Botanical Garden at Geneva, and the University of California, indicated by AA, Ge, NY, RH, and UC.

\section{Ilex oppositifolia sp. nov.}

Arbor glabra, 12-18 m. alta, ramis rigidis, teretibus, pallidis, internodiis $2-10 \mathrm{~cm}$. longis, ramulis in sicco subatris, subteretibus vel leviter compressis, plerumque $2-3 \mathrm{~mm}$. diametro; foliis stricte oppositis, crasse rigide coriaceis, sessilibus, ellipticis vel oblongo-ellipticis, $11-18 \mathrm{~cm}$. longis, $6-11 \mathrm{~cm}$. latis, rotundatis vel breviter acuminatis, basi late rotundatis, subcordatis vel distincte cordatis, interdum semiamplexicaulibus, in sicco supra pallide olivaceis vel brunneo-olivaceis, subtus plerumque brunneis, nervis primariis utrinque 10-12, subtus distinctis, elevatis, arcuato-anastomosantibus, reticulis laxis, elevatis; inflorescentiis cymosoumbellatis, lateralibus, $3-4 \mathrm{~cm}$. longis, floribus in ramulis paucis subumbellatim dispositis, pedunculo $1.5-2 \mathrm{~cm}$. longo, ramis primariis ad $6 \mathrm{~mm}$. longis; floribus o plerumque 4-meris, rariter 3-vel 5-meris, pallide albido-viridibus, pedicellis 3-4 mm. longis; sepalis late reniformibus, $0.5 \mathrm{~mm}$. longis, $1.5 \mathrm{~mm}$. latis, sub fructu junioribus persistentibus; petalis 4 (rariter 3 vel 5 ), ellipticis, rotundatis, $3 \mathrm{~mm}$. longis, $2 \mathrm{~mm}$. latis, imbricatis, sub anthesi patulis vel reflexis, basi leviter connatis; filamentis basi corollae adnatis, petalis alternantibus, $2 \mathrm{~mm}$. longis; antheris ovoideis, $1 \mathrm{~mm}$. longis, longitudinaliter 2-valvis; ovarii rudimento conico, rugoso vel subcostulato; fructibus globosis, rubris, in sicco atro-castaneis, laevibus, 5-6 mm. diametro, pyrenis 7 vel $8,3 \mathrm{~mm}$. longis.

British North Borneo, Mount Kinabalu, Penibukan, J. \& M. S. Clemens 40539, October 3, 1933 (AA, Ge, UC, RH), 31108, type (AA, NY) Jan. 16, 1933 (marked as equalling 30968), 31375 (NY), Jan. 24, 1933, and 50318 (AA, Ge, RH, UC), Oct.-Nov., 1933. On forested 
ridges altitude 1200 to $1500 \mathrm{~m}$. The holotype is in the herbarium of the Arnold Arboretum.

The specimens were distributed as doubtfully representing a celastraceous plant, and 40539 as a Microtropis. In spite of the strictly opposite leaves the species is in all respects an Ilex, buds, mature flowers, immature and mature fruits being available for study. In Ilex, other than by its opposite leaves, it is sharply differentiated by its large, rigidly coriaceous, sessile, broadly rounded, usually cordate and often semiamplexicaul leaves.

\section{Ilex zygophylla sp. nov.}

Frutex circiter $4.5 \mathrm{~m}$. altus, partibus junioribus inflorescentiisque leviter puberulis exceptis glaber; ramis pallidis, glabris, teretibus, internodiis plerumque $1-2 \mathrm{~cm}$. longis, ramulis ultimis subatris, obscure puberulis, circiter $1.5 \mathrm{~mm}$. diametro; foliis stricte oppositis, rigidis, crasse coriaceis, ellipticis, 2-4 cm. longis, $1.2-2.5 \mathrm{~cm}$. latis, utrinque late rotundatis, breviter petiolatis, junioribus utrinque obscure consperseque breviter puberulis, vetustioribus utrinque glaberrimis, margine revolutis, in sicco pallide brunneis, supra nitidis, vel junioribus atro-brunneis; nervis primariis utrinque 4-6, supra obsoletis vel subobsoletis, subtus paullo elevatis, arcuato-anastomosantibus, reticulis obsoletis vel subobsoletis; petiolo crasso, $1.5-3 \mathrm{~mm}$. longo; inflorescentiis lateralibus, in ramulis ultimis cymoso-umbellatis, paucifloris, obscure puberulis, circiter $1.5 \mathrm{~cm}$. longis, in sicco atris vel atro-brunneis, pedunculo ad $1 \mathrm{~cm}$. longo; floribus of 4-5-meris, parvis (immaturis), pedicellis $2-3 \mathrm{~mm}$. longis, puberulis; sepalis reniformibus, late rotundatis, extus obscure puberulis, circiter $0.5 \mathrm{~mm}$. longis, $1 \mathrm{~mm}$. latis; petalis (immaturis) imbricatis, glabris, ellipticis, rotundatis, saltem $2 \mathrm{~mm}$. longis; ovarii rudimento conico, longitudinaliter sulcato.

British North Borneo, Mount Kinabalu, Gurulu Spur at Lobang, J. E M. S. Clemens 51073 (AA holotype, Ge, RH, UC), December 14, 1933 , in the mossy forest, altitude about 2400 m., flowers "purple," distributed as Microtropis sp.

Although only staminate flowers are known, and these immature, this species is manifestly congeneric with the preceding one. It differs in its very much smaller, fewer-nerved, shortly but distinctly petioled leaves which are rounded but not cordate at their bases, and in its sparingly puberulent younger parts and inflorescences. Like Ilex oppositifolia Merr. this species has strictly opposite leaves with no traces of alternate ones.

Arnold Arboretum, Harvard University. 


\section{$2 \mathrm{BHL}$ Biodiversity Heritage Library}

Merrill, Elmer D. 1939. "Two New Species of Opposite-Leaved Ilex from Borneo." Journal of the Arnold Arboretum 20(2), 222-224. https://doi.org/10.5962/p.185410.

View This Item Online: $\underline{\text { https://www.biodiversitylibrary.org/item/33596 }}$

DOI: https://doi.org/10.5962/p.185410

Permalink: https://www.biodiversitylibrary.org/partpdf/185410

\section{Holding Institution}

Missouri Botanical Garden, Peter H. Raven Library

\section{Sponsored by}

Missouri Botanical Garden

\section{Copyright \& Reuse}

Copyright Status: In copyright. Digitized with the permission of the rights holder.

Rights Holder: Arnold Arboretum of Harvard University

License: http://creativecommons.org/licenses/by-nc-sa/3.0/

Rights: https://biodiversitylibrary.org/permissions

This document was created from content at the Biodiversity Heritage Library, the world's largest open access digital library for biodiversity literature and archives. Visit BHL at https://www.biodiversitylibrary.org. 